\title{
GENDER SPECIFICATION OF POLISH NOUNS NAMING PEOPLE: THE LANGUAGE SYSTEM AND PUBLIC DEBATE ARGUMENTS
}

\author{
Agnieszka KIEŁKIEWICZ-JANOWIAK \\ Adam Mickiewicz University, Poznań
}

Kiełkiewicz-Janowiak, A. (2019). Gender specification of Polish nouns naming people: language system and public debate arguments. Slovenščina 2.o, 7(2): 141-171.

DOI: https://doi.org/10.4312/slo2.0.2019.2.141-171

Changes in language practices take place against a backdrop of social pressures for greater gender equality. The topic of the current paper concerns the grammatical and social complexities of a language reform for gender fair representation in the Polish context. This "socially-motivated" language reform, which aims to enhance social equality, is underpinned but also challenged by the language system on the one hand and the public debate on the other. Therefore, the grammatical constraints afforded by the language system need to be investigated in the context of the social attitudes to gender relations in Poland, as well as attitudes to the proposed linguistic innovations. It is our aim here to reflect upon the current social debate about the process of ongoing language change, more specifically to consider the relevant linguistic and social arguments. These arguments are revealed in a close analysis of a range of texts of varying genre, social reach and significance, written as a reaction to the usage dilemmas often faced by speakers. The texts were collected between January 2014 and November 2019. The paper concludes with suggestions of the best policy to deal with a highly controversial socio-linguistic issue such as this one.

Keywords: feminization, gender morphology, Polish, inclusive language, public debate, gender policy 
Changes in language practices take place against a backdrop of social pressures for greater gender equality. The topic of the current paper concerns the grammatical and social complexities of a language reform for gender fair representation.

The "socially-motivated" language reform, which aims to enhance social equality, is underpinned but also challenged by the language system on the one hand and the public debate on the other. Therefore, the grammatical constraints afforded by the language system need to be investigated in the context of the social attitudes to gender relations in Poland as well as attitudes to the proposed linguistic innovations.

There is no consensus among linguists about a direct relation between language form and social structure, or more specifically between grammatical gender and gender discrimination in society. ${ }^{1}$ Therefore, there is no unequivocal support for socially motivated language use reform, which aims to bring about more gender fairness. ${ }^{2}$ An instructive and inspiring experiment, for linguists and lay language users alike, has been to reverse the established pattern and use the feminine form as generic. This has been done by individual authors in their writings (e.g. linguist Tove Skutnab-Kangas). ${ }^{3}$ A German linguist, Luise F. Pusch (1990), also proposed that the feminine forms be treated as basic, unmarked and appropriate for the generic meaning (see also Pusch, 1984). This sort of reversal of markedness may be treated as a "transitional

1 For example, in a recent publication about Polish feminitives, Wtorkowska (2019, p. 224), following some other Polish linguists, explicitly rejects the relation between gender as a grammatical category and extralinguistic reality. However, she does accept the more specific link between the grammatical gender of nouns and the sex of their animate referents. Ultimately, she acknowledges the asymmetry in referring to men and women in Polish, yet sees the tendencies towards neutralization or feminization as co-existing alternatives.

2 For example, in Poland a radical argument rejecting feminization because it does not support the feminist cause was voiced by the philosopher Katarzyna Paprzycka (2008) (see also section 3.4 below).

3 For example, to quote one of her texts: "This means that every researcher has to clarify for "herself" the relationship of intellectual knowledge to morality, duties, and struggle, and to come to terms with what for Wittgenstein is transcendental" (Skutnabb-Kangas, 2000, p. xxv). 
strategy", which would also reverse the experiences of women (and men) in being included (or not), and thus demonstrate the impact of language patterns. Additionally, this is a linguistically viable strategy in that it is economical in relying only on existing forms (Pauwels, 2003, p. 558-559). ${ }^{4}$

It is our aim here to reflect upon the current social debate about the process of ongoing language change, more specifically to consider the relevant linguistic and social arguments. The former are language-structure oriented, while the latter are language-function oriented, and have been popularly associated with rational thinking vs. emotions, and with being voiced, respectively, by linguists and lay language users.

The public debate about unequal language is defined by either of two general understandings of the relations between language and social reality: language reflects society vs. language constructs it. Thus, the former would assume that social change precedes language change, while according to the latter, language also has a social-constitutive function and can have an impact on social relations (cf. Halliday 1978; Lemke, 1992, p. 86). Thus, in the constructionist view, gender-biased language is considered an unfair representation of people in linguistic practices, which in turn perpetuate sexism.

The two approaches may both call for the use of language norms and practices so as to provide for a fair representation of men and women in language and for a fair shaping of human minds and social attitudes. However, while some people assume a change in society is prior to and thus reflected in a change in language, others - not necessarily rejecting this assumption - claim that consciously changing language patterns will raise speakers' awareness and attitudes, and thus support and maintain both social and linguistic change (see Popič and Gorjanc, 2018, p. 333 for details of the two approaches in the course of adopting gender-inclusive language in Slovene in the 1990s).

Gender specification, motivated by the need to represent women and men equally, means different things from the social and linguistic viewpoints. The

4 Pauwels defined the criterion as follows: "The proposed strategies should be capable of bringing about social change [...] with regard to the status of women and men in society [...] Proposed changes should, however, be also linguistically viable: an assessment should be made of the extent to which they affect the structure and use of a language" (Pauwels, 1998, p. 117). 
social considerations call for an adequate (and fair) representation, where people are referred to by words which recognize their identities and social roles. To provide for this, symmetrical reference is assured by the morphological means available in the language system. Additionally, as societies increasingly come to recognize an array of gender identities, and see socio-cultural gender as a continuum rather than in binary terms, language is expected to offer the potential of expressing this non-dominant understanding of gender. All in all, the grammatical system should make it possible to mark gender roles and identities not only as exclusive, but also inclusive, in ways that make gender either salient or inconspicuous, flexibly and at the speaker's discretion.

So far, different strategies have been applied in different languages to deal with the asymmetrical gender-marking believed to perpetuate gender inequality in society. This partly depends on the morphosyntactic structure of the language in question (Hellinger and Pauwels, 2007, p. 663). Gender neutralization, i.e. the tendency to remove gender-specific marking in generic contexts, is common in English (e.g. chairperson, flight attendant). However, where no such neutral reference is available, the masculine generic form persists, e.g. actor (i.e. actress is avoided). On the other hand, specification, which is aimed at including the missing forms to represent people's gender identities, is opted for in languages - such as German - with a robust grammatical gender system and productive suffixation processes. As lexical gaps usually concern the feminine gender, specification calls for feminization. This process is more complicated in some other languages which do not have one strongly preferred feminine suffix (e.g. Dutch or French). Even more so, Slavic languages have very rich gender morphology, which makes feminization linguistically challenging. ${ }^{5}$ Moreover, in Slavic languages (e.g. Czech, Slovak), but also in German, it is possible to apply both approaches, namely gender specification and neutralization. This is also the case in Polish, with a possibility to use gender indefinite forms (nouns such as personel [staff]) or the descriptive phrases including the gender-neutral noun osoba [person] (e.g. osoba kierująca samochodem [driver]), although

5 Where suffixation processes are complex and often blocked by morphological and phonotactic obstacles, graphemic marking may be applied to mark gender inclusivity in writing, for example the slash (der/die Lehrer/in), capital letters (einE LehrerIn) (Hellinger and Pauwels, 2007, p. 663), the underscore (Popič and Gorjanc, 2018) and the asterisk (Johnson, 2019). See also Steinhauber and Diewald, 2017, p. 46-47. 
these are admittedly rather long and sometimes clumsy. Polish also has gender-neutral ways of referring to people, such as the personal indefinite pronoun ktoś [someone], or the formal address pronoun państwo, unique to Polish and used to address or refer to a couple or group consisting of males and females (see also Łaziński, 2006, p. 45-46, 210).

\section{GENDER-INCLUSIVE LANGUAGE IN POLISH}

Feminization of nouns naming people has long been proposed and applied in the Polish language, and the history of the debate on the issue goes back to the beginning of the $20^{\text {th }}$ century, when women became increasingly present in professional and public positions, but nouns to refer to them were lacking. The introduction of feminine forms was often proposed and relatively easily accepted to adequately represent socio-cultural change (for a review see Woźniak, 2014; Małocha-Krupa, 2018). On the other hand, it was gender neutralization which was the preferred strategy after the Second World War, at the onset of communist rule, with its declared support for egalitarian values and the belief that using masculine nouns to refer to and/or address women actually raised their status (Szpyra-Kozłowska, 2019b; Woźniak, 2014). ${ }^{6}$ The above-described shifts of attitude and policy demonstrate how the language structure was closely related to what was happening in the social context. Awareness of the problematic nature of the masculine generic has been growing in Poland for the last few decades, informed mostly by those who believed the androcentric speech patterns were sexist, as well as inspired by the gender-fair policies implemented in other European languages.

In the Polish language, grammatical gender is marked on pronouns, nouns, adjectives and verbs (in the past tense and the analytical form of the future tense of imperfective verbs), as illustrated in the following sentence where the optional gender reference is expressed through splitting and the binary choice marked by a slash (male/female):

Ten/ta

This m./ f. teacher m./f. rewarded m./f.

$$
\text { nauczyciel/ka nagrodzit/a }
$$

dobra/ego

a $\operatorname{good} \mathrm{m} . / \mathrm{f}$. ucznia/uczennicę.

pupil m./f.

6 Compare, for example, with the Czech historical context, where socialism/communism supported the formation of feminitives as testifying to equality and emancipation (see Kolek and Valdrová, 2017). 
This example already points to a decision that must always be taken by the author of a text: how to code, in writing, the option present in the grammatical system. The underscore, unlike the slash, seems to better express gender pluralism (i.e. gender as an array of identities) beyond the binary male/female or masculine/feminine; one can say that it 'graphically contests' gender binarism.7 Any attempt to use gender-inclusive language - whether by means of slash or underscore - is fraught with problems due to the fact that patterns of deriving the feminine form from the masculine (generic) are variable and morphologically complex. This dilemma is present in other Slavic languages. For instance, a user of Slovene will be confronted by its "highly inflective nature and its prescriptive tradition" (Popič and Gorjanc, 2018, p. 329; see also Toporišič, 2004). Notably, feminine morphemes in Slovene - unlike in Polish - are very productive, and almost every masculine form has a feminine equivalent.

Using gender-inclusive language is not easy in Polish, either. For one thing, almost all feminine nouns are morphologically marked in that they are derivatives of masculine nouns. Graphically, the options may be separated by a slash and/or a hyphen, very rarely the underscore or star (asterisk). ${ }^{8}$ This may be written out in a number of ways, with either both the masculine and feminine full forms given or just the feminine suffix following the (basic) masculine form, as in a. and b. below:
a. inicjator/inicjatorka, inicjator lub inicjatorka [initiator]
b. inicjator/-ka, inicjator-ka, inicjator(ka)

Yet, because morphological alternation is very common, the full forms must be spelled out in some nouns:

filolog/filolożka [philologist m./f.]
bóg/bogini [god/goddess]
zabójca/zabójczyni [assassin m./f.]

where the feminine suffixes are respectively $-k(a)$, -in(i) and -yn(i).

7 See also Vičar and Kern (2017) for an analysis of the language practices used in Slovene to construct identities outside the normative binary gender system.

8 In Poland the underscore is rare, with the slash being the dominant way of marking an optional gender reference. 
However, the picture is complicated by the considerable multiplicity of feminine suffixes in Polish and their multifunctionality (see Łaziński, 2006, p. 254-258). The main feminine suffix is $-k(a)$, yet $-i n(i),-y n(i)-i c(a),-y c(a)$, -ow (a)) are also common though less productive. ${ }^{910}$ Derivation may, however, be blocked due to lexical, morphological and phonotactic ${ }^{11}$ reasons as well as extralinguistic factors. Accordingly, potential derivations may be problematic, such as szermierka [fencing] and architektka [woman architect], or even blocked (naukowiec m. [scholar], sportowiec m. [sportsman]), thus making the speaker's choices severely restricted (Łaziński, 2006, p. 195).

The question of which formations should be selected as feminine derivatives has been discussed in specialized publications and (less so) in public debates for well over 100 years - since women in Poland were allowed to enter higher education (1887) and won the right to vote (1918). The case of poset m. (member of parliament m.) illustrates a morphological dilemma: in 1919 a linguistics journal pondered the choice between poślina and poślica for a female MP, yet in 1923 the same journal resolved the matter in favour of postanka, suggesting it was already on its way to becoming established (Woźniak, 2014, p. 300).

Today, many nouns which are names of females are strongly pragmatically marked, either as innovations or - for the most part - because they index the lower status of the women referred to by these nouns compared to their masculine counterparts. Thus, minister $\mathrm{m}$. is the (statusful) name of a member of the government, while its (potential) feminine derivative, ministerka f., is largely unacceptable due to its negative, trivializing undertones ${ }^{12}$, while another possible derivative, ministra, is still far from being accepted in general use. In the case of occupational terms which are long-established in usage, such as lekarka f. [female physician] or dyrektorka f. [female head of institution],

9 Originally, most feminine suffixes carried the meaning of possession (mainly maritonymic: wife of $\mathrm{X}$ ).

10 For a brief overview, including other feminization processes see Szpyra-Kozłowska (2019b, p. 343-345).

11 Some feminine derivations are rejected for phonotactic reasons (e.g. pediatrka [pediadrician]), although the consonantal clusters considered problematic do occur in some Polish words, e.g. /trk/ in Piotrków, the name of a well-known Polish town.

12 This may be at least partially due to the fact that $-\mathrm{k}(\mathrm{a})$ is also a diminutive affix. Another reason might be that the affix in question is also used to refer to a non-personal referent (e.g. reżyserka [studio control room] or szoferka [truck cab]). 
they are (perceived to be) low(er) status and/or used informally. Last, but not least, non-linguistic factors come in the way, for instance the perception that feminized forms sound trivial, funny, or ugly. In fact, the ongoing, at times very emotional, online debate has given rise to much negative response, full of ridicule and often supported by peculiar lay linguistic 'expertise', as in the following forum entry:

bez_przekazu 28.04.13, 11:22

no to madrale-feministki do roboty:

jak bedzie wg was wygladal odpowiednik okreslania zenskiej formy „sedzia”? bo nic normalnego, poza „pani sędzia” nie przychodzi mi do glowy...

moje typy: sędziolożka (bo psycholozka), sędziarka (bo lekarka), sędzietyczka (bo dietetyczka), sędziatka (bo adwokatka).

macie jeszcze jakies pomysly, czy moze raczej skonczyc z tymi odmianami zenskimi i pozostac przy tym, co stare i sprawdzone?

ps. aha, a jak brzmi zenski odpowiednik chirurga? ${ }^{13}$

In the above forum entry, the author scorns the (im)possibility of finding feminine equivalents of names of professions, using the example of sędzia [judge] and generating a number of candidate (but non-existing) forms (sędziolożka, sędziarka, sędzietyczka, sędziatka), created by (false) analogy with existing feminine names of professions. In the postscript (ps.) the forum member challenges the "know-all feminists" to find a name for a female surgeon (chirurg). Indeed, this is not an easy task. The linguistically naive challenger proposes chirurżka or chirurgini, having selected the two most common feminine morphemes (-ka and -ini), which turn out to produce possible and transparent derivatives (though, in the former, chirurg $\mathrm{m}$. is wrongly assumed to be morphologically analogous to psycholog $\mathrm{m}$. [psychologist]). This is just a case of playing around with morphological rules, which in this case are very complex, involving multiple and multifunctional suffixes.

Summing up, grammatical gender specification is needed in order to achieve gender-fair representation in the Polish language. More exactly, the process involved is feminization, which can be either synthetic or analytic:

13 The original spelling retained. Source: http://forum.gazeta.pl/forum/w,16,144167266, 144167266, zenskie_odpowiedniki.html 
rzecznik m. [spokesman]

$\rightarrow$ rzeczniczka [spokeswoman] (synthetic)

$\rightarrow$ pani rzecznik [madam spokesman] (analytic) ${ }^{14}$

The latter is the more frequent choice, while the former is currently and quickly gaining ground.

In a recent paper Szpyra-Kozłowska (2019a) reports on a survey conducted among students, in which they were asked to generate feminine equivalents of masculine nouns naming people, those which - for various reasons - either do not exist in usage or are highly infrequent. The author's general conclusion is that the young participants in her study did not hesitate in proposing derivatives which were new formations or in supporting the less-used forms, even though, at the same time, they were rather conservative in opting for the most common suffix ( $-k a)$ to mark feminine gender. Among the range of obstacles to the feminization of nouns (semantic-pragmatic, morphological and phonological), it is the phonotactic considerations (with consonantal clusters /trk/, /rsk/) that seemed to have the most impact and bring about much hesitation. Yet, Szpyra-Kozłowska (2019a, p. 35) suggests that social reality, i.e. the frequent need to name female referents, alleviates the formal obstacles.

As evinced in the public debate, the incoming feminine forms are controversial (both to linguists and non-linguists) and still highly unstable, and there is a lot of uncertainty as to which form to use, particularly in institutional discourse. Therefore, 'double' feminine marking often occurs, as in pani psycholożka [madam psychologist f.], where pani combines indexing femininity and politeness, while psycholożka is a regular feminine derivative of the masculine form

14 Another option to refer to a woman is to use the inconsistent gender concord of verbs (and adjectives) in the feminine with masculine nouns, which are (by some) considered generic: nowa (f.) rzecznik (m.) ogłosita (f.)

[new (f.) spokesman (m.) announced (f.)]

Accordingly, the following are options for referring to the dean of a university faculty, of which only the first one is established and dominant in usage:

pani dziekan powiedziała

[madam dean (m.) said (f.)]

dziekana powiedziała

[dean (f.) said (f.)]

dziekan powiedziała

[dean (m.) said (f.)] 
psycholog [psychologist], which itself is far from generally accepted. Thus, at a university faculty, where usage is fluctuating in referring to the female dean, some would go for pani dziekana [madam dean (f.)], to mark both their respect for the dean (pani) and the gender of the person in this position (dziekana $\mathrm{f}$.), others though would claim that the address/reference title 'pani' followed by the name of the position in the masculine gender (dean $\mathrm{m}$.) is enough to express both meanings. Małocha-Krupa calls the former construction 'quasi-pleonastic' (2018, p. 97), one which shows apparent redundancy, but in fact serves a strategy to highlight and support women's professional achievement. ${ }^{15}$ The above-described formal contentiousness, and thus uncertainty, gives rise to variation.

One rule that might govern the use of feminine forms in texts whose authors wish to avoid gender-exclusivity may be that of applying both masculine and feminine gender whenever the context makes it clear that women are actually among the referents. This may have been the case with an open letter, written by Polish intellectuals in 2014 to the then minister of science and higher education, ${ }^{16}$ in defence of the humanities during the debate on the reform of the system to be incorporated in the proposed new law on higher education (discussed in detail in Kiełkiewicz-Janowiak 2018). The numerous (female and male) signatories of the letter were far from consistent in using gender-symmetrical terms, even when referring to themselves, as shown in the letter's first sentence (underlined by AK-J):

Szanowna Pani Ministro,

My, niżej podpisani, polscy intelektualiści, badacze i badaczki kultury pragniemy wyrazić solidarność z sygnatariuszami listu w obronie filozofii z 30 grudnia 2013 roku oraz listu otwartego polskich starożytników z 23 stycznia 2014 roku.

[Dear Madam Minister (f.),

We, the signatories, Polish intellectuals (m.pl.), researchers (m.) and researchers (f.) of culture, wish to express (our) solidarity with the signatories of a letter in defence of philosophy of December 30, 2013 and an open letter by Polish scholars of antiquity of January, 2014.]

15 In fact, as a new (female) dean at the Faculty of English at Adam Mickiewicz University in Poznań has just taken office, she has been referred to as "pani dziekana" by the former (female) dean.

16 List otwarty kulturoznawców i badaczy kultury do Ministry Nauki i Szkolnictwa Wyższego, prof. dr hab. Leny Kolarskiej-Bobińskiej, 17.02.2014 http://wyborcza. pl/1,95892,15472249,_List_otwarty_ naukowcow_do_minister_nauki_i_szkolnictwa. html\#TRrelSST\#ixzz38U4ksj6o 
Whenever the text did not explicitly refer to women (or men), masculine generics were applied, for example:

Polsce potrzebni (m.pl.) są nie tylko wykształceni (m.pl.) pracownicy (m.pl.), ale również kulturowo kompetentni (m.pl.) obywatele (m.pl.).

[Poland needs not only educated (m.pl.) workers (m.pl.), but also culturally competent (m.pl.) citizens.]

Such a restrictive rule is likely to limit the necessity of using 'excessive' splitting and allegedly make the text less clumsy and more comprehensible. The above sentence, when all adjectives and nouns referring to people (underlined) are doubled to include both males and females, would then be much longer (by five words) and less transparent:

Polsce potrzebni/potrzebne są nie tylko wykształceni pracownicy/wykształcone pracownicz-

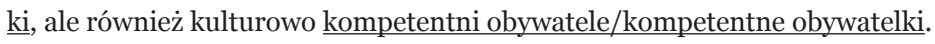

Ultimately, this 889-word long letter, while powerfully supporting the recognition of women as discourse participants (vide the salutation), includes at least seventeen masculine-generic nominal references to people (excluding pronouns, adjectives and verbs) when women are not explicitly named in the context.

\section{DEBATING gender ineQUALity AS A Linguistic AND A SO- CIO-POLITICAL PROBLEM}

As in the case of other central European countries that entered the European Union (e.g. Slovenia), Poland's accession in 2004 was followed by the adoption of many acts of EU legislation, including those which problematized gender inequality in the member states and, specifically, the presence of what was considered sexist in the language structure and language use (see Recommendation no. $R$ (90) 4 of the Committee of ministers to member states on the elimination of sexism from language (1990)). ${ }^{17}$ This, over the years, has triggered much debate on whether and how exactly the recommended law should be incorporated into the language system and language use practices.

17 One would hope these regulations would instigate the introduction and acceptance of internal guidelines for the use of gender-inclusive language in many institutions. However, although the implementation of usage recommended by the EU is apparent in many media outlets, it is not particularly consistent and does not seem to be strictly scrutinized by the editors. 
Tracing the history of the debate - both socially-based and grammar-based uncovers a number of themes, and much disagreement, even among linguists. The following presentation of the main lines of argument used in the debate is based on a close, critical analysis of a range of texts of varying genre, social reach and significance, written to voice (or in response to) arguments, or as a reaction to usage dilemmas often faced by the speakers. The texts were collected between January 2014 and November 2019.

\subsection{The linguistic arguments}

Polish society has a very strong normative tradition of issuing and obeying prescriptive pronouncements about language use. Speakers will keenly seek and follow the verdicts obtained from normative publications (e.g. dictionaries "of correct Polish"), advisory councils (e.g. Rada Języka Polskiego [Council for the Polish Language]) or other sources of normative advice (notably, Poradnia Językowa PWN [PWN Language Advisory Board]). These days, however, with the increasingly dynamic changes in language, printed publications are perhaps less influential, while the (interactive) electronic media offer easy contact with the people and institutions (mostly NGOs) who wish to alter language use patterns in the name of social equality.

In the course of the public debate the language system itself was appointed as a regulatory authority. This has been proposed (or suggested) by some linguists, who prefer to avoid relying on a claim about any direct link between language and social reality. They see the proposed reform for noun feminization as an occasion to fill in lexical gaps and to act towards symmetry in the morphosyntactic structures.

It fact, it seems easier to find linguists' approval for feminitives, if justified by means of language-internal arguments, such as: feminitives follow the rules of Polish morphology, their use is more economical (cf. linguistic validity), they are semantically precise and stylistically distinct (for a discussion see Małocha-Krupa, 2018a, p. 230).

In 2007, the Professor of Polish Marek Łaziński did not mind the introduction of new feminine derivatives because this "supports the transparency of the language system", yet he himself was not ready to adopt some forms which 
were still frowned upon by many speakers (Łaziński, 2007). In fact, he considered the claim of linguistic sexism as a 'metonymy' (in short, it is the text authors who are sexist, not the language system), which is dangerous if it leads to a simplistic interpretation of speakers' views (2006, p. 196, 198).

The strategy of neutralization, in contexts where gender is unknown and/or not relevant, may be implemented by splitting, where the gender of the participants is left undefined, yet is still explicitly marked as optional, i.e. binary. An argument for feminization grows from the fact that splitting in Polish requires so many interventions into a gender-exclusive utterance that it extends the text so as to make it close to incomprehensible (see the example in section 2 above). There is, however, no agreement that the rules of linguistic economy would otherwise always be violated. In fact, Łaziński (2006, p. 197, 209) claims that the use of masculine forms as 'universal' (i.e. generic) is very economical in the first place. Admittedly, empirical research is missing on the perception of the (generic) masculine in Polish, as well as on the cognitive load of processing gender-non-transparent references to people. It is possible that it is this processing effort which makes the masculine generics less rather than more economical.

In further scrutinizing the fine distinctions made in the language system, Łaziński (2006, p. 274) stresses a linguistic difference between (1) nouns that are used in address (tytularne), which may easily co-occur with pan/ pani (as in pani minister), and (2) other nouns which are not addressative, but referential, e.g. wykładowca/wykładowczyni [lecturer m./f.] (see also lekarz (referential) vs. doktor (addressative) [physician vs. doctor]). Łazinski suggests that because the addressative nouns explicitly point to the referent's sex (by being preceded by pan or pani, but also its concord with masculine or feminine adjectives or verbs), the feminine derivatives are blocked or superfluous. This is not the case with referential nouns, whose feminization is therefore justified.

To illustrate the claim that the feminization of Polish personal nouns may actually be a violation of the norms of the language, some linguists proclaim as "incorrect" those feminine gender innovations which are homonymous with other nouns which do not refer to people (e.g. dziekanka [dean's leave, informal], premiera [premiere, opening night]). This argument is hardly 
reasonable, as homonymy is in general common in language. The context of use on most occasions removes the ambiguity, which is readily acknowledged by Polish linguists (e.g. Skubalanka 1997, p. 164; Łaziński, 2006, p. 259-260) as well as ordinary language users.

The way the process of feminization is unavoidably related to social roles and relations is shown by the following correlation: the higher the prestige of the social function of the referent, the more restricted the feminine derivation process (Łaziński, 2006, p. 253-254). Małocha-Krupa (2018a, p. 191-192) argues that this correlation has also been caused by ideological-cultural factors.

\subsection{The 'historical' argument}

The standard language ideology informs but also empowers arguments that encourage observing the rules of grammar which are represented as 'traditional' (see the similar context of the Slovenian language as described by Popič and Gorjanc, 2018). In fact, the language-related appeal to the historical significance of one form or another may be misleading (or plain manipulative), as usage over the decades has inevitably been changing, and the argument will always be based on the arbitrary choice of the linguist who makes it. However, as Popič and Gorjanc (2018) show for the case of Slovenian, the linguistically grounded argument is "linked to other ideological positions within society that contradict equality (...)" (Popič and Gorjanc, 2018, p. 331), and is only apparently supported by linguistic reasons.

One way in which the argument may be arbitrary or biased is by ignoring some historical patterns which may serve as examples of good practice for today. In fact, some of the feminine forms which are considered controversial innovations and are even contested today turn out to have once been in common use (in some circles, at least). For example, the feminine forms of academic positions, such as doktorka, docentka, were popular in the 1920 s and the 1930 s (Kiełkiewicz-Janowiak and Pawelczyk 2014, p. 361; see also Woźniak, 2014; Hołojda-Mikulska, 2016, p. 96; Scheller-Boltz, 2017; Małocha-Krupa, 2018a).

Two Polish universities first admitted female students in the late 1890s, in the midst of much controversy about whether female brains were capable of intellectual achievement (see Małocha-Krupa 2018a, p. 86-99). Before then and 
into the $2 \mathrm{O}^{\text {th }}$ century women's growing professional activity called for nomination decisions and evinced usage which was highly variable (Małocha-Krupa, 2018a, p. 97). Strikingly, the selection of options afforded by the language system was exploited one hundred years ago in much the same way as it is today (analytic forms, synthetic derivatives), yet until the Second World War the latter were fairly common and sanctioned by the language norms.

In December 1922 the University of Poznań awarded an honorary doctorate to the outstanding Polish chemist, and winner of two Nobel Prizes, Maria Skłodowska-Curie. The University Senate document then confirmed "udzielenie stopnia doktorki wszech nauk lekarskich honoris causa” [awarding honorary doctor's (f.) degree in medical sciences]. ${ }^{18}$

Tracing the history of the use of and acceptability for feminitives shows that arguments once vital later lost their power, depending on the perceived value of their connotation. For instance, in the middle of the $2 \mathrm{O}^{\text {th }}$ century it was the masculine generic forms which were preferred for naming prestigious professions and functions, because the use of the feminine derivatives was then perceived as diminishing the status of the referent (see Obrębska-Jabłońska, 1951). Today, many of the feminine names of professions seem to have gained relatively equal status with their masculine counterparts (e.g. dziennikarka, [journalist f.]), unlike some others, which seem just as well-established but lack prestige (compare lekarz m. - and lekarka f. [doctor] m. and f.).

Significantly, the feminine derivatives of names of less prestigious occupations have found their way to general Polish more easily, while - in contrast - they have been resisted in the case of the more prestigious professions and functions traditionally, and almost exclusively, held by men (Hołojda-Mikulska, 2016, p. 95).

\subsection{The 'legal' argument}

The arguments not easily discarded are those calling for a precise reference to the identity of persons in legal documents. Paweł Knut, on behalf of the Polish Society of Anti-Discrimination Law, prepared an expert report on Polish

18 Minutes from the ninth session of the Senate of the University of Poznań of 15.12.1922. Source: Archiwum UAM, Protokoły posiedzeń senatu Uniwersytetu Poznańskiego 21.01.1922 - 16.07.1923, sygn. 15/S/3. 
normative acts, concluding that most Polish legislation documents use nouns in the masculine gender to refer to (all) people.

This approach will not work in a number of specific cases, in which the law refers to females exclusively. For example, the Polish Law on Higher Education (of 12.09.1990) uses the (pseudogeneric) masculine grammatical form to refer to "an academic teacher (m.) who is pregnant": "Nauczyciela akademickiego w ciąży lub wychowującego dziecko [w wieku] do jednego roku nie można zatrudniać w godzinach ponadwymiarowych bez jego zgody" (Art. 131.3.). [An academic teacher (m.) who is pregnant or is taking care (m.) of a child under age 1 may not be given overtime without his (m.) consent.] This contentious phrasing, repeated in several following amendments (for example, in a version passed in 2012), was strongly contested by some, dubbed as "unfortunate" by others, but was nevertheless retained in the new Law of Higher Education and Science, passed in July 2018 (Art. 127.8).$^{19}$ In fact, the use of the feminine referent may in some constructions be imprecise and confusing, as in

$\begin{array}{llll}\text { jedna } & z & \text { kandydatek } & \text { na premiera } \\ \text { one f. } & \text { of } & \text { the candidates f.pl. for } & \text { the prime minister } \mathrm{m} .\end{array}$

where the speaker marks the femaleness of the referent, but at the same time restricts the set of candidates to female candidates only. There is hardly an unequivocal, and thus legally precise, way of referring to a female candidate as one of a group of male and female candidates; the options would be either:

$\begin{array}{llll}\text { jedna } & z & \text { kandydatów } & \text { na premiera } \\ \text { one f. } & \text { of } & \text { the candidates m.pl. } & \text { for the prime minister } \mathrm{m} .\end{array}$

or the following, probably closest to the inclusive interpretation, with a present participle in the genitive case, which obscures the $\mathrm{f} . / \mathrm{m}$. distinction:

$\begin{array}{llll}\text { jedna } & \mathrm{z} & \text { kandydujących } & \text { na urząd premiera } \\ \text { one } \mathrm{f} & \text { of } & \text { the (ones) running for the post of prime minister } \mathrm{m} .\end{array}$

19 Possibly, the legislators may have meant to refer - in one phrase - to both parents, allowing for the father taking care of the child. Moreover, as some linguists argue, critics do not seem to find the use of the singular form (throughout the article) problematic, as we agree that it symbolically refers to all academic teachers. 
Similarly, controversy has emerged over whether the Polish Nobel laureate for literature for 2018, Olga Tokarczuk, is getting enough credit being called "a great writer" in the feminine gender (pisarka) - is she 'great' among female writers only, or does the masculine form (pisarz) show more respect?

The examples above show the consequences of the complexity of the grammatical system in real life contexts which require unambiguous reference to human subjects. However, they also suggest that, especially in extended discourse, speakers have ways to disambiguate the reference they make to others.

\subsection{The does-sex/gender-matter question?}

On the other hand, the status of the feminine (or feminized) forms has also been called to question. One might ask, following Katarzyna Paprzycka, a phi-losopher at the University of Warsaw: czy ministra nie jest ministrem? [is "ministra" (f.) not a minister (m.)?]. In other words, is the biological sex of a person holding an important public function at all relevant? Or, further still, is foregrounding their sex not offensive to them? This of thinking is in fact not new, since the linguist Witold Doroszewski asserted in 1948:

W zasadzie sprawa płci ministra jest tak samo pozbawiona związku z jego funkcją społeczno-państwową jak i kolor jego oczu. (Doroszewski, 1948, p. 69)

[In principle, the question of the minister's sex is just as unrelated to their function as is the colour of their eyes.] ${ }^{20}$

Accordingly, Paprzycka is herself against the active propagation of language use change, and specifically against normalizing grammatical feminine gender forms as the only ones for referring to women. She asserts:

Jestem feministą, jak każdy trzeźwo myślący człowiek, który rozumie sytuację kobiet. Jestem jednak przekonana, że w interesie polskiego feminizmu leży sprzeciwienie się feminizacji (choć nie feminizowaniu) w szczególności nazw zawodów. (Paprzycka, 2008)

[I am a feminist (m.), like every sensible human being (m.) who understands the situation of women. However, I am convinced (f.) that it is in the interest of Polish feminism to oppose feminization (although not feminizing), particularly names of occupations.]

She does, however, accept feminization as a linguistic process which is occurring, as we speak, in response to social change: "Proces feminizowania jest

20 Significantly, at the time Doroszewski made this observation there was not a single female minister in the Polish government. 
faktem językowym odzwierciedlającym zmieniającą się rzeczywistość.” [The process of feminizing [nouns] is a linguistic fact which reflects the changing reality.]. Thus, Paprzycka supports the reflecting-but-not-shaping role of language in relation to social reality.

\subsection{Power of the normative tradition}

This argument raises the question of whether linguistic matters should be interfered with, whether a natural process of change should be regulated with a normative action called 'language reform'. Scheller-Boltz (2017) observes: "The norm that the generic masculine is gender-neutral and gender-inclusive is based on ideologies. (...) Norms are not natural phenomena. Norms are created by institutionalized authorities within a society (...)" (Scheller-Boltz, 2017, p. 86).

The linguistic norm-oriented public sphere in Poland, where speakers constantly seek linguists' advice, is still full of the rather conservative opinions of linguists, who are sceptical about social interventions into language structures. For example, Professor Jerzy Bralczyk, a well-known authority on language use, stated in a recent radio interview, in a somewhat impersonal way, a wish that language were "self-governing” ("Otóż chciałoby się, żeby język był jednak samostanowiacy się"). ${ }^{21}$ This kind of reserved attitude has been sanctioned by the Council for the Polish Language, which proclaimed in its 2012 statement on feminitives that "people cannot impose anything on language" ("językowi nie da się niczego narzucić"). ${ }^{22}$ The argument on the part of many linguists and lay users alike is that certain forms are "natural", "traditional", "established" or simply "grammatical". Additionally, it is argued that the generic form in question refers to the (social) function, not to the person holding it.

Whether the somewhat restrained attitude of the linguists is increasingly acceptable or not, the public debate is still far from settled. Even academic conferences organized to discuss gender equality in language frequently include politically engaged arguments, while more popular forums are full of

21 https://www.youtube.com/watch?v=bn_VFVMJJy8

22 Stanowisko Rady Języka Polskiego w sprawie żeńskich form nazw zawodów i tytułów przyjęte na posiedzeniu plenarnym Rady 19 marca 2012 roku, at: http://www.rjp.pan. pl/index.php?option =com_content\&view=article\&id=1359:stanowisko-rady-jzyka-polskiego-w-sprawie-eskich-form-nazw-zawodow-i-tytuow 
passionate statements. Indeed, most comments on the internet are emotional and sometimes offensive:

Jestem fizykiem (z wyksztakcenia) i programistą (z zawodu). Szału dostaję, jak ktoś mi wyjeżdża z "fizyczka" czy "programistkq". Brzmi to cokolwiek idiotycznie. [I am a physicist (by education) and a programmer (by trade). It drives me crazy when somebody uses "physicist (f.)" or "programmer (f.)". It sounds somewhat idiotic.]

Irytuja mnie nazwy takie jak psycholożka czy fizyczka, ale jeśli okaże się, że stały się powszechne to nie widzę powodów do walki z wiatrakami. [I get irritated by names such as psychologist (f.) or physicist (f.), but if it turns out that they have become commonly used, I don't see why I should tilt at windmills.]

Psycholog to stowo ładne, mądre, nobliwe i „wyższe”, jak mężczyzna, a psycholożka to stowo śmieszne i glupie, jak kobieta. [Psychologist (m.) is a word which is nice, clever, noble and "higher", as a man is, while psychologist (f.) is funny and stupid, like a woman.]

In fact, even expert opinion uses highly expressive descriptions such as $d z i-$ wne, dziwaczne, ryzykowne, pokraczny, dziwolag, horror! [strange, bizarre, risky, awkward, freak, horror!]

With the internet as an open resource, many speakers of Polish who otherwise remain unrecognized as experts on language use, have appointed themselves as authorities, with blogs being a popular outlet for their opinions. The following excerpt is an example of how a blogger named Anna Polona addresses the topic of feminine names of professions in a personal way, describing her bumpy road to acceptance, under the heading "Dawniej wszyscy byliśmy ludźmi, teraz wiele osób (i osobniczek) podkreśla, że jesteśmy kobietami i mężczyznami." [We all used to be people, now many persons (m. and f.) stress that we are women and men.]:

Mój sprzeciw budzi nie tyle samo zjawisko, jakim jest pojawianie się $w$ języku nowych, żeńskich form nazw zawodów, stanowisk i tytułów, ile uparte dążenie feministek do jego upowszechniania i zalegalizowania. Jestem kobieta, nie odczuwam jednak potrzeby podkreślania na każdym kroku aspektów ptci. Nie rażą mnie męskie nazwy zawodów używane $w$ odniesieniu do kobiet $i$ wcale nie uważam, że to skutek wpajania przez lata patriarchalnych przekonań. Pozwólmy, by język "sam" ewoluowat. (Anna Polona, 2018). ${ }^{23}$

[My protest is raised not exactly by the appearance of new, feminine forms of professions, occupations, positions and titles, but rather be the stubborn insistence of feminists about the propagation and legal use of these forms. I am a woman but I don't feel the need to stress

23 Blog entry for Polszczyzna (nasza) powszednia, at: http://polszczyznapowszednia. pl/2018/10/04/ premiera-pilotka-dramaturzka/ 
gender issues all the time. I am not bothered by the use of masculine gender forms with reference to women, and I don't believe this is a consequence of the infiltrating of patriarchal values. Let us allow language evolve on its own.]

In fact, the whole blog entry includes two references to the idea that people need to "get used" (PL. oswoić się) to the new or uncommon feminine forms. This also surfaces in many linguists' accounts on the social fate of innovations.

\subsection{The practices of naming other and self: Social and political performance}

Apart from the controversies related to the linguistic 'legitimacy' of the new, feminine derivatives, the performative aspect of their use should be considered. Opting for the new feminine names of occupations and functions may be deemed a performative act of aligning with feminist views and, for that matter, a more generally liberal political position.

Inspired by the ideologies of equality (and feminism in particular), people wish to make themselves represented in the social space by symbolic means, among them the signs of language. Thus, they do not only position themselves, but also hope to be able to subvert the established social relations: the centrality of masculinity, the inflexible assignment of social roles and the lack of appreciation for some members of society.

An example of how members of an occupational group have decided to make themselves recognized and appreciated by means of self-naming is the case of female truck drivers in Poland: ${ }^{24}$ although the grammatical system would predict the derivation of "kierowczyni", by analogy with sprzedawca m./ sprzedawczyni f. [shop assistant m./f.] , dowódca m./dowódczyni f. [commander m./f.], they have chosen to call themselves (and be called) kierowniczki f. pl. - a form homonymous with the less specific, but more prestigious kierowniczka f. sg. [(female) head of] - a woman in charge of an institution (such as school, shop, etc.) or group (such as team, etc.). The self-appointed name allows the users to define their rank by borrowing that of another name for an occupation/function. In other words, by claiming a name for themselves, they have also made a claim to a higher status.

24 For example: https://m.facebook.com/story.php?story_fbid=1980370652061098\&id=579 751362123041 
This idea of bringing about the upgrading of social and professional functions (of women) through the use of language is to be found not just in current linguistic writing on the topic, but has been around for decades. In the middle of the $2 \mathrm{O}^{\text {th }}$ century the upgrading power of language was attributed to the use of masculine forms to refer to women (e.g. Obrębska-Jabłońska, 1949, p. 2). On the other hand, today the reason why some speakers use the still uncommon feminine nouns is exactly the intention to make them ordinary and unmarked through increasingly frequent occurrence, and thus to minimize their perception of indexing relatively low prestige (Wtorkowska, 2019, p. 228). In both cases, however, the social impact achieved is dependent on the status of the social functions and activities involved: the use of the masculine form about a low status occupation would not bring about prestige (e.g. sprzataczka f. [cleaner]). To mark the very high prestige of a top-quality hairdresser (fryzjerka f.) the common strategy would be to use a different term (i.e. stylistka f. fryzur [hair stylist]).

In a very recent attempt to mark their feminine identity, a group of twenty newly elected (left-wing) MPs in the Polish parliament appealed to the Speaker of the Sejm (the lower house of the Polish Parliament) that they should be identified as women, and wished this to be reflected in, among other things, the name plaques marking their seats in the sessions chamber. ${ }^{25}$ They received no formal reply, yet the plaques with their names have just been installed, to the dismay of the MPs concerned, with the masculine (generic) form poset $\mathrm{m}$. $[\mathrm{MP}]$ preceding the their names. Importantly, the appeal also received numerous internet comments ridiculing the initiative.

\subsection{Language and culture - reciprocal influence?}

Most accounts of the relation between grammatical gender and socio-cultural gender roles and identities present language as basically reflecting social

25 The appeal read as follows: "My niżej podpisane Posłanki-Elektki (...) zwracamy się z prośbą o uwzględnienie naszej płci w nazewnictwie zarówno w dokumentach będących w obiegu Sejmu RP, jak i we wszelkiego rodzaju przedmiotach przeznaczonych do naszego użytku. Szczególnie zależy nam na takich przedmiotach jak: karty do glosowania czy tabliczki, które wskazują nasze miejsce na Sali plenarnej. Pragniemy, aby sformułowanie Posłanka było tym, które na wspomnianych przedmiotach oraz dokumentach się pojawi.” Source: https://oko.press/jestesmy-poslankami-a-nie-poslami-20-parlamentarzystek-lewicy-pisze-do-kancelarii-sejmu-chca-zmian-tabliczek/\# 
reality and culture, as phrased, for instance, by Małocha-Krupa: "centralna (rdzenna) pozycja męskości znajduje swój ślad kulturowo-językowy” [the central (core) position of masculinity finds its trace in language and culture] (Małocha-Krupa, 2018a, p. 199). The constitutive role of language is rarely explicitly stated, even if tacitly assumed. An example of discourse which implicitly acknowledges the impact of language structures on society is present in calling for naming the referents (people, problems, phenomena, etc.) which do not (yet) have a name, which - more effectively than silence - may introduce the previously unnamed (people, problems, etc.) into the social space (see also Małocha-Krupa, 2018a, p. 200-201), and perhaps respect or destigmatize them. Linguists who closely follow the systematic changes involving feminativa in Polish differ in the extent to which they acknowledge the power of language to construct reality. Significantly, Łaziński plays down the reflecting function of language in that he stresses the lack of a one-to-one correspondence:

(...) język nie ma być dokładnym zwierciadłem rzeczywistości, lecz co najwyżej jej niedokładna mapq z użyciem konwencji znaków i symboli, których powinniśmy być świadomi. (Łaziński, 2007) ${ }^{26}$.

[...language is not to be an exact mirror of reality, but - at most - an inexact map of it, using conventional signs and symbols, which we should be aware of]

At the same time, he seems to distance himself from the constitutive power of language and recommends a practical attitude in his response to speakers asking expert advice: "Nie szukajmy $w$ języku sprawiedliwości, ale też starajmy się, by byt logiczny i wygodny." [Let's not look for fairness in language; we'd better make it logical and convenient.] (Łaziński, 2007). While for many years explicitly supporting the introduction of (new) feminine derivatives, Łaziński (2019) recently suggested that the efforts toward gender symmetry in language, however (un)successful, should rather be treated as an expression of women's and men's need to increase the recognition and visibility of hitherto marginalised gender groups. He brought forward, presumably as examples of good practices, the usage in the statutes of two European universities. The Senate of the University of Leipzig voted in 2013 in favour of adopting the feminine forms of academic titles (e.g. Professorin) as generic in university

26 http://sjp.pwn.pl/poradnia/haslo/ginekolozka-naukowczyni-i-in;7882.html 
documents. The new statute of Adam Mickiewicz University in Poznań allows the use of both feminine and masculine forms of names of academic positions and functions, ${ }^{27}$ although the document itself applies the masculine forms as generic.

Judging by the growing intensity of the public debate on these issues, an increasing number of people in Poland have become convinced that discussing matters related to socio-cultural gender is socially consequential. Accordingly, the ways of referring to people and their activities, in particular the choice of nominal forms, will impact the referents' reception and status. Individuals and organizations calling for greater sensitivity and recognition of gender roles inspired the movement towards greater equality and fairness, especially through the adequate use of feminine grammatical forms, which were either to be re-introduced or, oftentimes, newly created, as the grammatical system affords much potential for the derivation of feminitives.

The above agenda for language use reform has raised much controversy. Apart from those who consider the new forms superfluous in view of the availability of (alleged) generics, others prefer to let language change occur at its own pace, following and reflecting social change. On the other hand, supporters of the constructionist view of the role of language believe that social change may be brought about and advanced through proposing (or even imposing) new, egalitarian usages before they become common in society. The latter position, however, means foregrounding sex/gender as a social dimension pertinent to any topic and context.

The growing awareness of the relevance of linguistic practices for social equality and the well-being of citizens may be exemplified by the increasing sensitivity to the process of grammatical feminization in the Polish language. As suggested by Małocha-Krupa (2018a, p. 252), speakers' reflection may result in a tendency to extend the normative pronouncements made by language authorities and, therefore, to supplement the repertoire of nouns naming people with the missing (or disused) feminine forms. The example is set by the liberal, pro-egalitarian communities of speakers, whose usage is spreading through society at large. Although corpus data give results that show new

27 See Statut Uniwersytetu im. Adama Mickiewicz w Poznaniu, Art. 5.3. at: https://amu. edu.pl/__data/assets/pdf_file/0032/88781/Statut-UAM.pdf 
trends whose direction and pace is still difficult to estimate, the influx of feminine nouns can be related to feminist discourses which have been gaining significance in Poland for the last decade (Małocha-Krupa, 2018a, p. 255). Importantly, the influx of feminine nouns now considered neologisms may be perceived as the reintroduction of forms once current in the Polish language. In fact, the history of feminitives over the last 200 years reflects the history of attitudes to acknowledging women's roles in social life. It seems that the productivity of feminine suffixes, potentially operative in Polish, gets activated by social movements. The resulting variation is partially brought about by speakers seeking transparent morphological options (or simply experimenting with the complex and multifunctional gender morphemes in Polish). However, in a speech community so strongly dependent on the prescriptive pronouncements of normative authorities, usage is variable until those authorities give it their blessing.

At the end of the day, the question is whether it is indeed relevant and worthwhile to make socio-cultural gender marked linguistically. The discussion reported on above includes voices supporting the linguistic invisibility of referents' social gender, for the sake of foregrounding their more relevant features, such as expertise or psychological capabilities, locally relevant in a social situation. For example, in the discourse of academic writing the well-established, though not uncontroversial, convention has been to background the sex of the author by referring to them by their surname only. The argument is that in the vast majority of scholarly texts the author's academic background and their expertise is all that matters. However, more and more academics realise that readers (and media text consumers alike) will usually conjecture the authors' sex anyway and find it hard to accept when it is not transparent. As a result, most readers tend to assume that the majority of scholarly authors are male, guided by the conviction that men outnumber women in academia. ${ }^{28}$

The problem of the implementation of language change once again brings together the two sources of influence discussed here: language users and experts. The former, even if willing to be leaders in instigating and spreading

28 In general, women publish fewer research papers on average than men (Gender in the global research Landscape, 2017). With regard to scientific publications, women comprise less than $30 \%$ of the authors. In sociology, women are $41 \%$ of all authors (data for 1990-2011; West et al., 2012). 
linguistic innovations, will typically look up to the authority of the latter, who - hopefully - understand the complex connection between language and the dynamics of social reality.

The true challenge to further studies is to uncover how the language-internal mechanisms, dictated by the availability of morphological means of changing the structure of one aspect of language, are strongly impacted by the essentially social (and highly emotional) public debate on the topic.

\section{DISCUSSION}

In the public debate some prioritize the language structure, others the social reality. The Polish language does have the (morphological) potential for representing concepts in a gender-fair way, assuming that gender equality may be attained by symmetrical grammatical gender marking. However, the complexity of its gender-related morphology impedes the implementation of change (or reform).

There is no doubt that proposing a language reform and instigating a public debate raises the awareness of social problems and provokes people to consciously modify their speech practices (or not) based on the personal consideration of arguments. In fact, the language system is not easily malleable. It may be true that "people cannot impose anything on language" but, at least from a sociolinguistic viewpoint, language is the people. Changing people's mindsets will ultimately change the structure of the language they speak. However, future research might verify whether changing the language structure first may speed up the process of mental and societal change.

Two factors seem relevant here: (1) time (as defining the stage of implementing of the reform), and (2) the explicit association of language reform with (feminist) ideology. Most linguists acknowledge that the incoming feminine forms in Polish are generated in accordance with the word formation rules of the language. At the same time, they understand the fact that users are not accustomed to many of the innovations, and it must take some time before they accept them. This process is ongoing as we speak, and it is an open question whether it should be rushed. Some claim that it will be easier if the change becomes - in the public consciousness - dissociated from being 
ideologically motivated (e.g. Wtorkowska, 2019, p. 230). "Using gender-fair language outside the feminist context may help to make it "normal'" (Formanowicz et al., 2015). ${ }^{29}$

Inspired by the views of Agnieszka Małocha-Krupa (2018a, p.c.), a linguist and expert on Polish feminitives, I would propose a usage practice which might be deemed a "transitional policy" - gender should be explicitly and adequately marked in ways that do not burden the message and its communicative value. In the Polish language there exist numerous morphological means to make known the gender of the participants of communication, of which not all need to be utilized at the same time. This accords with the most recent approach to gender inclusivity, which aims at such linguistic marking as represents a range of gender identities assumed and claimed by people in situated ways. Thus, speakers are not only no longer made invisible in/by the language, but are also allowed agency in making their identity salient in contexts of their choice and thus freely use linguistic means for performative acts.

Another matter is whether the gender-inclusive language debate in Poland at all addresses issues of gender binarism. When compared, the directions of language reform and change in Polish and English are mostly contrasting: while gender specification (in Polish) - through introducing and/or propagating the hitherto missing (mostly) feminine terms - maintains and extends the binary distinctions, gender neutralization (in English) - by introducing gender neutral terms - blurs the feminine/masculine division, while foregrounding other characteristics of the referent. Although Polish has some, alas limited, potential for gender-neutral phrasing, this has not been a priority. It may be argued that the grammatical gender system of the Polish language perpetuates gender binarism. On the other hand, it is possible that Polish society has not (yet) recognized the alleged oppressiveness of genderism.

29 However, Ehrlich and King (1992) claim that "the association of non-sexist language with high-status groups is necessary for the adoption of a non-sexist language policy. The implementation of such a policy and/or guidelines, however, does not guarantee immediate and total compliance." Among the factors for successful implementation they list "the perception of language reform as part of social reform" (Ehrlich and King, 1992, p. 178). 
The Polish language, with its relatively complex morphology, finds the process of gender specification difficult, both in formal and social terms. The feminization of nouns naming people requires suffixation and consequent changes in a term's morphological environment (concord with verbs and adjectives, complicated splitting constructions, etc.). Because the feminine suffixes are often multifunctional or homonymous with other suffixes (e.g. diminutive), as well as challenged by semantic and phonological problems, an easy switch is questionable. In spite of these difficulties, the use of feminativa in Poland is on the rise, both based on impressionistic counts and on corpus analyses (the latter are admittedly scarce due to lack of long-term and balanced corpora of Polish; see Małocha-Krupa, 2018a, p. 277).

What is then the best policy to promote gender equality in and through language? In a country with rather conservative attitudes, both to gender roles and language use norms, it might be sensible to dissociate the issue from the political agenda it is in fact part of. Whether occasional or systematic use is made of the feminitives, it will contribute to the spread and empowerment of these forms, for the sake of gender equality. I also recommend slow and consistent awareness raising, which would gradually persuade more and more people of good will and understanding. With time, innovative language patterns (such as feminine derivatives or new, independent formations) will become more frequent and common, while proposals for language reform will win increasing support from those who believe that linguistic and social practices are interrelated. It is likely that those who feel personally threatened by the incoming change might subvert or reject it. By this time, though, it may (and will) be too late to reverse the processes guided by gender-fairness in language use.

\section{REFERENCES}

Doroszewski, W. (1948). Rozmowy o języku. Warszawa: Radiowy Instytut Wydawniczy.

Elsevier. (2017). Gender in the Global Research Landscape: Analysis of research performance through a gender lens across 20 years, 12 geographies, and 27 subject areas - report. Retrieved from https://www.elsevier. com/__data/assets/pdf_file/ooo8/265661/ElsevierGenderReport_final_for-web.pdf 
Formanowicz, M. M., Cisłak, A., Horvath, L. K., \& Sczesny, S. (2015). Capturing socially motivated linguistic change: how the use of gender-fair language affects support for social initiatives in Austria and Poland. Frontiers in Psychology, 31(6), 1617. https://doi.org/doi: 10.3389/fpsyg.2015.01617

Hellinger, M., \& Pauwels, A. (2007). Language and Sexism. In M. Hellinger \& A. Pauwels (Eds.), Handbook of Language and Communication: Diversity and Change (pp. 651-675). Berlin: Walter de Gruyter.

Hołojda-Mikulska, K. (2016). Dyskusje o feminatywach na łamach „Języka Polskiego" w latach 1945-1989. Język Polski, 2, 89-97.

Johnson, I. P. (2019). Gender neutral wording is making German ridiculous, asserts association. Deutsche Welle News. Retrieved from https://www.dw.com/ en/gender-neutral-wording-is-making-german-ridiculous-asserts-association/a-47801450

Kiełkiewicz-Janowiak, A. (2018). »Szanowna Pani Ministro! My, niżej podpisani, polscy intelektualiści, badacze i badaczki kultury (...)« - obserwując zmianę językową. In U. Okulska-Łukawska, U. Topczewska \& A. Jopek-Bosiacka (Eds.), Wybrane zagadnienia lingwistyki tekstu, analizy dyskursu i komunikacji międzykulturowej - In memoriam Profesor Anny Duszak (1950-2015) (pp. 235-258). Warszawa: Instytut Lingwistyki Stosowanej UW.

Kiełkiewicz-Janowiak, A., \& Pawelczyk, J. (2014). Language and gender research in Poland: An overview. In J. Holmes, M. Meyerhoff and S. Ehrlich (Eds.), The Handbook of Language, Gender and Sexuality (pp. 355-377). London: Wiley Blackwell.

Kienpointner, M. (2000). Feministische Linguistik. Trends, Resultate, praktische Anwendungen. In. S. Klettenhammer \& E. Pöder (Eds.), Das Geschlecht, das sich (un)eins ist? (pp. 228-245). Innsbruck: Studienverlag.

Kłosińska, K. (2009, 25. 08.). Przechodzieńka nie przejdzie. Polityka.

Kolek, V., \& Valdrová, J. (2017). Die tschechische sprachwissenschaftliche Geschlechertforschung im Spiegel der bohemistischen Fachzeitschriften. Osnabrücker Beiträge zur Sprachtheorie, 91, 147-165.

Łaziński, M. (2006). O panach i paniach. Polskie rzeczowniki tytularne $i$ ich asymetria rodzajowo-ptciowa. Warszawa: Wydawnictwo Naukowe PWN. 
Łaziński, M. (2007). Poradnia językowa PWN: Ginekolożka, naukowczyni i in. Retrieved from https://sjp.pwn.pl/poradnia/haslo/ginekolozka-naukowczyni-i-in;7882.html

Łaziński, M. (2019). Pani końcówka. Polityka, 46 (13.11.-19.11.2019).

Małocha-Krupa, A. (2013). Feminizacja współczesnego języka polskiego. In A. Małocha-Krupa, K. Hołojda, P. Krysiak, W. Pietrzak. (Eds.), Równościowy savoir-vivre w tekstach publicznych (pp. 93-99). Warszawa: Biuro Pełnomocnika Rządu do spraw Równego Traktowania.

Małocha-Krupa, A. (2018a). Feminatywum w uwikłaniach językowo-kulturowych. Wrocław: Oficyna Wydawnicza ATUT.

Małocha-Krupa, A. (2018b). Opis leksykograficzny feminatywum. (Nie) możliwości zobiektywizowania. In M. Bańko and H. Karaś (Eds.), Między teoriq a praktyką. Metody wspótczesnej leksykografii, 1, 151-165.

Warszawa: Wydawnictwa Uniwersytetu Warszawskiego.

Obrębska-Jabłońska, A. (1949). O żeńskich formach tytułów i nazw zawodów. Poradnik Językowy, 4, p. 1-4.

Obrębska-Jabłońska, A. (1951). Pani doktor za granicą. Język Polski, XXXI, 180-182.

Paprzycka, K. (2008). Feministyczny głos przeciw feminizacji form męskich. O dylematach na temat psychologów, psycholożek i psycholożków. Nauka, 4, 121-131. Retrieved from http://www.racjonalista.pl/ kk.php/s,6662

Pauwels, A. (2003). Linguistic sexism and feminist linguistic activism. In J. Holmes and M. Meyerhoff (Eds.), The handbook of language and gender (pp. 550-570). Oxford: Basil Blackwell.

Popič, D., \& Gorjanc, V. (2018). Challenges of adopting gender-inclusive language in Slovene. Suvremena lingvistika, 86, 329-350. https://doi. org/10.22210/suvlin.2018.086.07

Pusch, L. (1984). Das Deutsche als Mannersprache. Frankfurt am Main: Suhrkamp.

Pusch, L. (1990). Alle Menschen werden Schwestern: Feministische Sprachkritik. Frankfurt am Main: Suhrkamp.

Scheller-Boltz, D. (2017). The feminisation of Russian and Polish: A feminist idea? Or a real tendency in language? HCC, LVIV, 84-90. 
Sczesny, S., et al. (2016). Can gender fair language reduce gender stereotyping and discrimination?. Frontiers in Psychology, 7(25). doi: 10.3389/ fpsyg.2016.00025

Skutnabb-Kangas, T. (2000). Linguistic genocide in education - or worldwide diversity and human rights? Mahwah: Lawrence Erlbaum.

Steinhauber, A. and Diewald, G. (2017). Richtig gendern. Wie Sie angemessen und verständlich schreiben. Berlin: Duden Verlag.

Szpyra-Kozłowska, J. (2019a). „Premiera”, „premierka” czy „pani premier”? Nowe feminatywy w badaniu ankietowym. Język Polski, 2, 22-40. Retrieved from https://www.ceeol.com/search/article-detail?id=780107

Szpyra-Kozłowska, J. (2019b). Feminitives in Polish: A study in linguistic creativity and tolerance. In A. Bondaruk and K. Jaskuła (Eds.), All around the word: papers in honour of Bogdan Szymanek on his 65th birthday (pp. 339-364). Lublin: Wydawnictwo KUL.

Vičar, B. and Kern, B. (2017). Možnosti jezikovnega izražanja nebinarnih transspolnih identitet v slovenščini. Dialogi, 53(11/12), 223-237.

West, J. D., et al. (2012). The role of gender in scholarly authorship. PLOS One, 8(7). https://doi.org/10.1371/journal.pone.0066212

Woźniak, E. (2014). Język a emancypacja, feminizm, gender. Rozprawy Komisji Językowej Łódzkiego Towarzystwa Naukowego, LX, 295-312.

Wtorkowska, M. (2019). O żeńskich formach nazw zawodów, tytułów i stanowisk w języku polskim. Slavistična revija, 67(2), 223-232. Retrieved from https://srl.si/ojs/srl/article/view/2019-2-1-10 


\section{SPOLJENJE SAMOSTALNIKOV ZA POIMENOVANJE OSEB V POLJŠČINI: JEZIKOVNI SISTEM IN ARGUMENTI V JAVNI RAZPRAVI}

Spremembe v jezikovnih praksah se odvijajo hkratno z družbenimi pritiski za večjo spolno enakopravnost. Tema članka zadeva slovnične in družbene posebnosti jezikovne reforme za spolno pravično naslavljanje na Poljskem. »Družbeno motivirana « jezikovna reforma, katere namen je izboljšati družbeno enakopravnost, se opira na jezikovni sistem in javno razpravo, oboje pa reformo hkrati tudi zavira. Zaradi tega je treba raziskati slovnične omejitve jezikovnega sistema v kontekstu odnosa družbe do odnosov med spoli na Poljskem kot tudi odnosov do predlaganih jezikovnih sprememb. Naš namen je osvetliti trenutno družbeno razpravo o procesu uvajanja jezikovnih sprememb, in sicer na primeru jezikovnih in družbenih argumentov. Tako analiziramo argumente, podane $\mathrm{v}$ razpravi in zbrane za analizo nabora besedil različnih žanrov, dometa in relevantnosti, ki je bila objavljena kot odziv na zapisovalne težave, o katerih so poročali pisci. Besedila smo zbirali med januarjem 2014 in novembrom 2019. Članek zaključimo s predlogi za najboljši način, kako se soočiti s tem izjemno kontroverznim sociolingvističnim vprašanjem.

Ključne besede: feminizacija, poljščina, vključujoč jezik, javna razprava, spolna politika, morfologija spola,

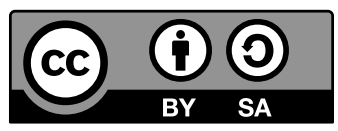

To delo je ponujeno pod licenco Creative Commons: Priznanje avtorstva-Deljenje pod enakimi pogoji 4.o Mednarodna. / This work is licensed under the Creative Commons Attribution-ShareAlike 4.o International.

https://creativecommons.org/licenses/by-sa/4.o/ 